\title{
PEMBERDAYAAN EKONOMI MASYARAKAT MELALUI APLIKASI TEKNOLOGI PENGOLAHAN DODOL NANGKA DAN SUSU BIJI NANGKA DI KABUPATEN LOMBOK BARAT
}

\author{
Nurhayati ${ }^{1}$, Asmawati ${ }^{11}$, Syirril Ihromi ${ }^{1}$, Marianah'1), Adi Saputrayadi' ${ }^{11}$ \\ 1)Program Studi Teknologi Hasil Pertanian, Fakultas Pertanian, Universitas Muhammadiyah Mataram, Mataram, NTB, Indonesia \\ Corresponding author : Nurhayati \\ E-mail: nurhayati.faperta.ummat@gmail.com
}

\section{Diterima 03 November 2020, Disetujui 10 November 2020}

\begin{abstract}
ABSTRAK
Desa kekeri merupakan salah satu desa sentra produksi nangka di Kabupaten Lombok Barat. Produksi buah nangka di desa tersebut melimpah namun tidak diikuti dengan harga jual yang tinggi. Ketika musim buah nangka tiba, harga jual nangka tidak memiliki nilai sedikitpun karena penjualan buah nangka dalam keadaan segar tanpa adanya proses pengolahan lebih lanjut. Berdasarkan kenyataan tersebut, dilakukan kegiatan pengabdian yang bertujuan untuk : (1) Memberikan pemahaman dan pengetahuan kepada masyarakat tentang nutrisi, manfaat dan olahan buah nangka (2) Menjelaskan dan memberikan percontohan kepada ibu - ibu rumah tangga dan remaja putri tentang aplikasi teknologi pengolahan dodol nangka dan susu biji nangka. (3) Memberikan ketrampilan kepada kelompok masyarakat khususnya ibu - ibu dan remaja putri tentang bagaimana cara meningkatkan pendapatan rumah tangga serta pemenuhan gizi keluarga melalui aplikasi teknologi pengolahan dodol nangka dan susu biji nangka. Pelaksanaan kegiatan ini berlangsung dengan sukses dan lancar sesuai dengan rencana. Kegiatan pengabdian pada masyarakat ini mampu meningkatkan pengetahuan masyarakat tentang nutrisi, manfaat dan olahan nangka. Selain itu juga mampu meningkatkan keterampilan peserta penyuluhan untuk mengolah dodol nangka dan susu biji nangka. Diharapkan kegiatan pengabdian ini dapat bermanfaat bagi peserta kegiatan untuk menjadi ide rintisan usaha dodol nangka meningkatkan pendapatan keluarganya serta dapat memenuhi gizi keluarga melalui aplikasi teknologi pengolahan susu biji nangka.
\end{abstract}

Kata kunci: pemberdayaan masyarakat; dodol nangka; susu biji nangka; kekeri.

\begin{abstract}
Kekeri village is one of the centers for jackfruit production in West Lombok Regency. The production of jackfruit in the village is abundant but not accompanied by a high selling price. When the jackfruit season arrives, jackfruit's selling price is meager because the sale of jackfruit is fresh without further processing. Based on this fact, service activities were carried out aimed at: (1) Providing understanding and knowledge to the public about nutrition, benefits, and processed jackfruit (2) Explaining and giving examples to housewives and young women about the application of jackfruit dodol and jackfruit seeds milk processing. (3) Providing skills to community groups, especially mothers and young women, on increasing household income and fulfilling family nutrition by applying jackfruit lunkhead and jackfruit seed milk processing. This activity was carried out successfully and smoothly according to plan. This community service activity can increase public knowledge about nutrition, benefits, and processed jackfruit. Besides, it can also improve the extension participants' skills to process jackfruit lunkhead and jackfruit seed milk. It is hoped that this service activity can be useful for activity participants to become a pilot idea for dodol jackfruit business to increase family income and fulfill family nutrition by applying jackfruit seed milk processing.
\end{abstract}

Keywords: community empowerment; jackfruit dodol; jackfruit seed milk; kekeri

\section{PENDAHULUAN}

Tanaman nangka merupakan jenis tanaman yang banyak ditanam di daerah tropis, seperti Indonesia (Andyarini \& Hidayati, 2017). Di Indonesia, buah nangka dapat hidup di setiap daerah sepanjang tahun dan bukan merupakan tanaman musiman. Salah satunya terdapat di pulau Lombok yakni tepatnya di Kecamatan Gunung Sari. Daerah sentra produksi nangka tersebar di beberapa desa salah satunya di desa Kekeri dan Ranjok.

Melimpahnya produksi nangka di desa tersebut tidak diikuti dengan harga jual yang tinggi. Apalagi ketika musim buah nangka tiba 
harga jual nangka tidak memiliki nilai sedikitpun karena penjualan buah nangka dalam keadaan segar tanpa adanya proses pengolahan lebih lanjut.

Buah nangka sebagai buah segar, termasuk salah satu buah yang tidak tahan lama atau cepat rusak. Jumlahnya yang banyak karena berbuah sepanjang tahun, mengakibatkan sebagian akan membusuk dan tidak dapat dipasarkan dan hal ini akan merugikan produsen. Pengolahan buah nangka menjadi aneka produk pangan dapat dijadikan sebagai solusi untuk mengatasi karakteristik buah nangka tersebut.

Buah nangka yang banyak dimanfaatkan adalah daging buah baik yang muda maupun yang sudah tua. Buah nangka muda dapat diolah menjadi sayur seperti gudeg dan gulai. sedangkan buah nangka tua dapat dinikmati menjadi berbagai variasi produk yang lebih tahan lama seperti jus, sirup, selai, manisan, dan dodol.

Dodol merupakan salah satu makanan tradisional yang khas dan popular bagi masyarakat Indonesia, bahkan di setiap daerah memilik nama kekhasan tersendiri (Setiavani et al., 2018). Ada dua jenis pengolongan dodol yaitu dodol yang terbuat dari beras ketan dan dodol yang terbuat dari buah - buahan (Haryadi, 2006). Buah - buahan yang sering digunakan dalam pembuatan dodol seperti durian, nanas, pisang, strawberry dan juga nangka. Pengolahan nangka menjadi dodol dapat memperpanjang masa simpan sampai 113 hari (Nisak, et al., 2014). Olahan dodol nangka sangat digemari oleh masyarakat untuk dijadikan sebagai oleh oleh khususnya di Pulau Lombok.

Pengolahan nangka menjadi dodol sering kali menimbulkan limbah sebanyak $65 \%$ - 80\% dari berat keseluruhan. Limbah dodol nangka dapat berupa kulit, jerami atau dami dan biji nangka. Biji nangka kurang dimanfaatkan dan dikenal orang, Keberadaan biji nangka hanya dimanfaatkan terbatas sebagai bibit atau pakan ternak. Berdasarkan hasil survey didaerah tersebut, biji nangka hanya dimanfaatkan dengan direbus, dibakar maupun disangrai.

Pemanfaatan biji nangka belum dilakukan secara optimal, padahal biji nangka mengandung nilai gizi yang tinggi. Berdasarkan Data Komposisi Pangan Indonesia, (2018) biji nangka mengandung karbohidrat sebesar $36,7 \%$. Menurut Swami et al., (2012) menyebutkan bahwa setiap 100 gram biji nangka juga mengandung mineral yang cukup tinggi fosfor (200 mg), kalsium (33 mg) dan besi $(1,0 \mathrm{mg})$. oleh karena itu biji nangka merupakan salah satu sumber karbohidrat dan mineral yang sangat penting bagi tubuh.

Salah satu pemanfaatan Limbah biji nangka adalah dengan mengolahnya menjadi susu biji nangka. susu biji nangka mengandung fosfor dan kalsium lebih tinggi daripada susu kedelai (Nusa et al., 2014). Apalagi dengan kondisi saat ini harga susu cukup mahal, sehingga, susu biji nangka bisa menjadi salah satu alternative untuk mencukupi kebutuhan nutrisi. Ditinjau dari sisi lain pemanfaatan biji nangka mempunyai prospek bisnis yang menguntungkan. Namun di Desa Kekeri, pengolahan nangka menjadi dodol nangka dan susu biji nangka tidak sedikit yang mengetahui. Hal ini disebabkan kurangnya pengetahuan masyarakat dalam aspek teknologi olahan buah nangka

Berdasarkan kenyataan tersebut maka perlu dilakukan kegiatan pengabdian sebagai transfer teknologi berupa penyuluhan dan pelatihan tentang aplikasi teknologi pengolahan dodol nangka dan susu biji nangka sebagai upaya meningkatkan pendapatan sekaligus pemenuhan gizi masyarakat. Tujuan dari kegiatan ini meliputi (1) Memberikan pemahaman dan pengetahuan kepada masyarakat tentang nutrisi, manfaat dan olahan buah nangka (2) Menjelaskan dan memberikan percontohan kepada ibu - ibu rumah tangga dan remaja putri tentang aplikasi teknologi pengolahan dodol nangka dan susu biji nangka. (3) Memberikan ketrampilan kepada kelompok masyarakat khususnya ibu - ibu dan remaja putri tentang bagaimana cara meningkatkan pendapatan rumah tangga serta pemenuhan gizi keluarga melalui aplikasi teknologi pengolahan dodol nangka dan susu biji nangka.

\section{METODE}

wilayah Kegiatan ini telah dilaksanakan di Muhammadiyah Mataram di Desa Kekeri Kecamatan Gunung Sari, dimana wilayah tersebut merupakan tempat salah satu tim penyuluh/pengabdian, menjadi pembimbing KKN. Mitra kegiatan ini adalah ibu - ibu rumah tangga dan remaja putri Desa Kekeri Kecamatan Gunung sari yang berjumlahkan sekitar 30 orang.

Metode pendekatan yang telah digunakan dalam dalam kegiatan pengabdian ini adalah PRA (Participatory Rural Appraisal yaitu melibatkan masyarakat dalam kegiatan (Ihromi et al., 2020). Adapun tahapan kegiatan yang dilaksanakan siantaranya:

a. Diskusi dan persiapan kegiatan

b. Penyuluhan dalam bentuk ceramah memberikan teori-teori tentang nutrisi 
nangka dan biji nangka serta beberapa olahannya.

c. Pelatihan dalam bentuk demonstrasi pembuatan dodol nangka dan susu biji nangka. Bahan - bahan yang diperlukan dalam kegiatan ini antara lain nangka, biji nangka, gula pasir. Peralatan yang digunakan antara lain, pisau, baskom, dandang, kompor, panci, sendok, wajan, blender, dan lain - lain.

Kegiatan ini dievaluasi dengan dilakukannya pengamatan secara langsung terhadap partisipasi mitra dari pertanyaan yang diajukan oleh tim pengabdian

\section{HASIL DAN PEMBAHASAN}

Kegiatan ini telah dilaksanakan di desa Kekeri Kecamatan Gunung Sari dimana wilayah tersebut merupakan tempat salah satu tim penyuluh/pengabdian pada masyarakat ini, menjadi pembimbing KKN. Desa ini berjarak \pm $20 \mathrm{~km}$ dari kampus Universitas Muhammadiyah Mataram dengan sarana transportasi yang cukup memadai bagi yang memiliki kendaraan pribadi, dan yang tidak memiliki kendaraan pribadi hanya bisa mengakses desa tersebut menggunakan ojek. Adapun untuk sarana komunikasi di desa kekeri tersebut sudah dapat diakses melalui mobile phone.

Kegiatan ini dilaksanakan oleh 5 orang dosen, 14 mahasiswa KKN, dan sekitar 30 orang masyarakat yang terdiri dari ibu-ibu rumah tangga, ibu-ibu hamil dan menyusui serta remaja-remaja putri. Kegiatan ini dimulai dari beberapa tahapan diantaranya :

\section{Diskusi dan Persiapan kegiatan}

Kegiatan pengabdian diawali dengan dengan diskusi dengan antara perwakilan tim mahasiswa KKN dan tim pengabdian terkait tentang produk yang akan didemonstrasikan dan waktu pelaksanaan. Setelah tercapai kesepakatan, maka tim mahasiswa dan warga masyarakat mempersiapkan peralatan yang dibutuhkan untuk kegiatan penyuluhan dan pelatihan yang akan dilakukan. Begitu pula dengan tim pengabdian mempersiapkan materi kegiatan dan bahkan mencoba membuat produk susu biji nangka terlebih dahulu untuk dijadikan contoh kegiatan pelaksanaan berlangsung.

\section{Penyuluhan tentang nutrisi, manfaat nangka dan biji nangka}

Kegiatan ini dilakukan dengan metode ceramah yang disampaikan oleh salah satu tim yang memiliki bidang keahlian pangan dan gizi seperti yang disajikan pada Gambar 1 .

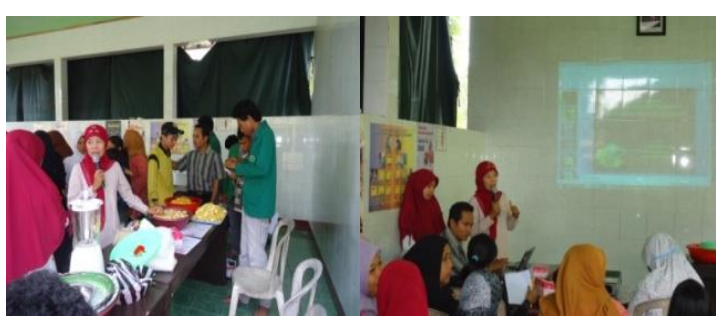

Gambar 1. Penyuluhan komposisi nutrisi buah dan biji nangka

Informasi yang disuluhkan oleh tim pengabdian dirasakan sangat bermanfaat oleh para peserta karena banyak para peserta yang tidak mengetahui kandungan gizi, manfaat dan jenis jenis olahan dari buah nangka beserta turunannya. Hal ini disebabkan karena sebagian peserta yang hadir hanya memiliki tingkat pendidikan rata rata SMP, sehingga pengetahuan akan mafaat nangka pun baru diketahui sejak kegiatan berlangsung.

Tim penyuluh menyampaikan bahwa buah nangka kaya akan nutrisi. Nangka mengandung vitamin $A$, vitamin $C$, thiamin, riboflavin, kalsium, kalium, zat besi, natrium, seng, dan niasin di antara banyak nutrisi lainnya. Nangka memiliki kandungan kalori yang rendah: $100 \mathrm{~g}$ nangka hanya mengandung 94 kalori (Mukprasirt \& Sajjaanantakul, 2004). Nangka juga kaya akan kalium dengan kandungan 303 mg dalam 100. Studi menunjukkan bahwa makanan yang kaya kalium membantu menurunkan tekanan darah. Manfaat lain dari nangka adalah sebagai sumber vitamin $\mathrm{C}$. Tubuh manusia tidak menghasilkan vitamin $\mathrm{C}$ sehingga seseorang harus makan makanan yang mengandung vitamin $C$ untuk mendapatkan manfaat kesehatannya. Manfaat kesehatan vitamin C adalah sebagai antioksidan yang melindungi tubuh dari radikal bebas, memperkuat sistem kekebalan, dan menjaga kesehatan gusi (Umesh et al., 2010).

Buah nangka merupakan salah satu buahbuahan sebagai sumber protein terkaya $(1,72$ g), jika dibandingkan dengan buah-buahan lainnya seperti pisang $(1,09 \mathrm{~g})$, mangga $(0,82$ $\mathrm{g})$, ara $(0,75 \mathrm{~g})$ dan nanas $(0,54 \mathrm{~g})$. buah nangka juga kaya akan kalsium (24 mg) apabila dibandingkan nanas (3 $\mathrm{mg})$ dan mangga (11 mg) (Waghmare et al., 2019). Buah nangka juga menjadi sumber yang kaya akan berbagai mineral seperti N, P, K, Ca, Mg, S, Zn, Cu, dll (Maurya \& Mogra, 2016).

Nangka mengandung fitonutrien: lignan, isoflavon, dan saponin yang memiliki manfaat kesehatan yang sangat luas. Fitonutrien ini memiliki sifat antikanker, antihipertensi, antiulcer dan antipenuaan properti. Kandungan fitonutrien yang terdapat pada buah nangka dapat mencegah pembentukan sel kanker 
dalam tubuh, dapat menurunkan tekanan darah, melawan sakit maag, dan dapat memperlambat proses degenerasi sel yang membuat kulit tampak muda dan segar (Swami et al., 2012).

Selain itu, cita rasa dan aroma buah nangka yang eksotik sehingga sangat digemari untuk dikonsumsi dalam keadaan segar.

Selain buah, bagian nangka yang memiliki gizi yang cukup tinggi adalah biji nangka. Biji nangka memiliki manfaat gizi yang cukup besar dan memiliki berat sekitar $10 \%$ hingga $15 \%$ dari berat buah (Hossain, 2014), bahkan (Hadi et al., 2017) menyebutkan bahwa biji nangka memiliki berat rata-rata sepertiga dari berat buahnya.

Biji nangka menyediakan pasokan protein, serat, dan pati yang cukup tinggi. Bijinya kaya akan serat makanan dan vitamin B kompleks dan karena kandungan seratnya yang tinggi, mereka membantu menurunkan risiko penyakit jantung, mencegah sembelit dan meningkatkan berat badan. Biji nangka juga mengandung pati resisten, yang mengontrol gula darah dan menjaga kesehatan usus. Biji nangka memiliki aktivitas antimikroba, yaitu mencegah penyakit bawaan makanan (Maurya \& Mogra, 2016) dan bijinya mengandung lektin penting yang dikenal dengan nama jacalin, yang digunakan sebagai alat untuk mengevaluasi sistem kekebalan tubuh orang yang terinfeksi HIV.

Potensi biji nangka (Arthocarphus heterophilus lamk) yang besar belum dieksploitasi secara optimal. Sangat rendahnya pemanfaatan biji nangka dalam bidang pangan hanya sebatas sekitar $10 \%$ disebabkan oleh kurangnya minat masyarakat dalam pengolahan biji nangka. Sehingga kegiatan ini juga dilakukan penyuluhan berbagai macam olahan nangka baik itu daging buah dan biji nangka. Kegiatan ini dipandu oleh tim pengabdian yang memiliki bidang keahlian teknologi dan rekayasa proses pengolahan pangan seperti yang disajikan pada Gambar 2.

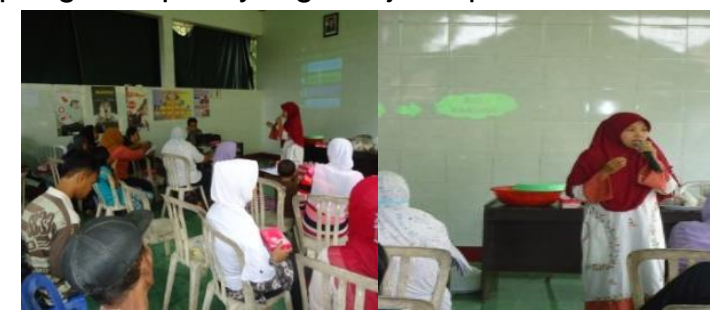

Gambar 2. Penyuluhan teknologi pengolahan nangka

Penelitian tentang pengolahan nangka telah banyak dilakukan salah satunya menjadi produk dodol. Dodol merupakan makanan semi basah (Intermediate Moisture Food) dengan kadar air sedang kira-kira 15-50 \% dan aktivitas air kurang dari 0,9.

Dodol sangat populer di kalangan masyarakat Indonesia sebagai panganan tradisional khas yang harus dilestarikan. Bahkan dodol telah menjadi icon oleh-oleh khas bagi beberapa daerah. Oleh karena itu pengembangan dodol memiliki prospek yang baik untuk dikembangkan (Wulandari et al., 2014).

Pengembangan dodol dapat dijadikan sebagai prospek bisnis yang menguntungkan khususnya bagi warga masyarakat Desa Kekeri yang hadir menjadi peserta kegiatan pengabdian ini. Sehingga ketika penyuluhan tentang olahan dodol nangka, para peserta sangat antusias mengikuti kegiatan menyimak secara seksama apa yang disampaikan oleh tim penyuluh, beberapa ibu-ibu mengangkat tangan untuk bertanya kepada tim penyuluh. Selain bertanya, para peserta juga menyampaikan bahwa ketika nangka sudah dipanen langsung dijual kepasar, ada yang juga yang diolah untuk digoreng dan ada juga yang dimasak ketika buah nangka masih muda. Pengolahan nangka dengan berbagai produk dapat dilihat pada Gambar 3.

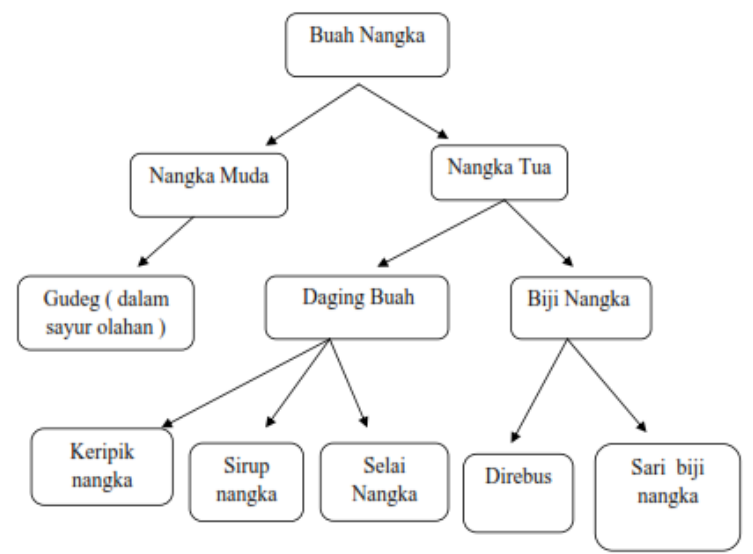

Gambar 3. Diagram Pemanfaatan buah nangka

(sumber : Rachmawati, 2011)

Materi yang diberikan ke peserta dirasa sangat menarik, terutama ketika tim penyuluh menyampaikan bahwa biji nangka dapat diolah menjadi susu. Pemanfaatan biji nangka sebagai produk susu tidak hanya memiliki nilai ekonomis, akan tetapi yang paling penting sebagai pemenuhan gizi keluarga. Semua peserta yang didominasi oleh ibu ibu hamil menanyakan pentingnya dan manfaat susu biji nangka untuk gizi ibu dan janin seperti yang disajikan pada tabel 1 . 
Tabel 1. Informasi nilai gizi susu biji nangka

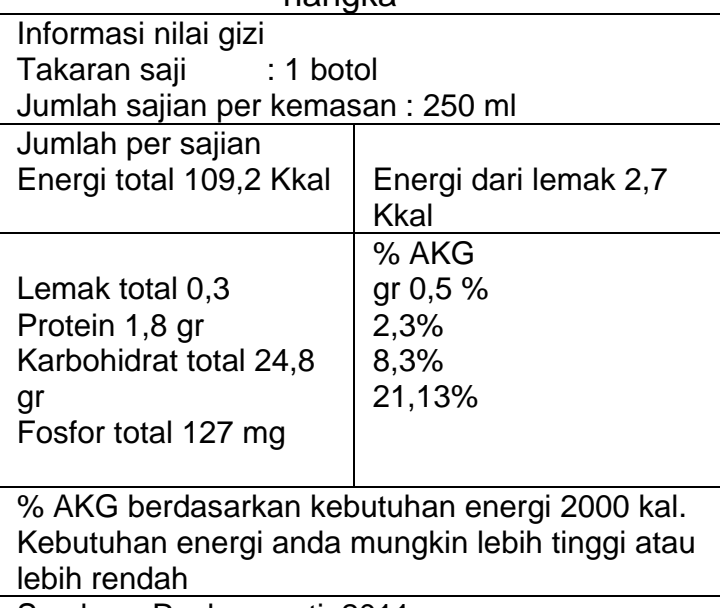

Sumber : Rachmawati, 2011

Susu biji nangka kaya akan fosfor dan tinggi akan karbohidrat serta kandungan proteinnya. $\mathrm{Di}$ sisi lain rendahnya kandungan lemak/kolesterol dari susu biji nangka tentu akan sangat aman untuk kesehatan jantung para peminumnya. Fosfor mempunyai berbagai fungsi dalam tubuh diantaranya : (1) Mengatur pengalihan energi, melalui proses fosforilasi fosfor mengaktifkan berbagai enzim dan vitamin $B$ dalam pengalihan energi dan metabolisme karbohidrat, lemak dan protein pada berbagai reaksi di dalam tubuh. (2) Absorpsi dan transportasi zat gizi. Dalam bentuk fosfat, fosfor berperan sebagai alat angkut untuk membawa zat-zat gizi menyeberangi membran sel atau di dalam aliran darah. (3) Fosfat memegang peranan penting sebagai buffer untuk mencegah perubahan tingkat keasaman cairan tubuh. Ini terjadi karena kemampuan fosfor mengikat tambahan ion hidrogen. Angka kecukupan fosfor yang dianjurkan rata-rata sehari disajikan pada Tabel 2 .

Tabel 2. Angka kecukupan fosfor (mg) yang dianjurkan rata-rata sehari. Sumber : BPOM,

\begin{tabular}{ll}
\multicolumn{2}{c}{2007} \\
\hline Bayi 0-6 bulan & $: 100$ \\
\hline Bayi 7-23 bulan & $: 320$ \\
\hline Anak-anak (2-5 tahun) & $: 400$ \\
\hline Umum & $: 600$ \\
\hline Ibu hamil dan menyusui & $: 600$
\end{tabular}

Berdasarkan analisis fungsi dan kebutuhan fosfor tersebut, maka untuk anak anak dapat terpenuhi kebutuhan fosfornya dengan meminum 2 gelas susu biji nangka ( 500 $\mathrm{ml}$ ) dan untuk remaja/orang dewasa dapat terpenuhi dengan meminum 3 gelas susu biji nangka $(750 \mathrm{ml})$ dalam seharinya.

Konsumsi susu semakin hari semakin meningkat, namun harga susu justru terus meningkat. Oleh karena itu, konsumsi susu biji nangka menjadi salah satu alternatif pemenuhan gizi ibu hamil. Seperti yang disampaikan oleh Sutarto et al., (2018) bahwa faktor gizi buruk yang dialami oleh ibu hamil maupun anak balita, serta kurangnya pengetahuan calon ibu mengenai gizi sebelum kehamilan menjadi penting untuk diketahui oleh para remaja putri dalam mempersiapkan diri sebagai calon ibu.

Berdasarkan hasil observasi atau pengamatan langsung pada aspek keaktifan dan keseriusan peserta ketika kegiatan berlangsung, maka dapat dikatakan bahwa kegiatan penyuluhan nutrisi, manfaat dan olahan buah nangka berhasil dilaksanakan.

\section{Pelatihan dan demonstrasi pembuatan dodol nangka dan susu biji nangka}

Kegiatan pelaksanaan pengabdian selanjutnya yakni pelatihan dan demonstrasi pengolahan dodol nangka dan susu biji nangka seperti yang disajikan pada Gambar 4 dan 5 .

Pengolahan dodol nangka mengikuti prosedur seperti yang dilakukan oleh dodol nangka yang diolah di UD. Warna Sari Narmada dengan sedikit modifikasi (Astuti, 2019). Pengolahan dodol yang terbuat dari buah - buahan seperti nangka umumnya menggunakan metode bleeding dalam pembuatannya. Metode ini merupakan matode pembuatan dodol dengan menggunakan sedikit atau tidak sama sekali tepung beras dan santan (Setiavani et al., 2018). Pengolahan dodol nangka dilakukan dengan menggunakan bahan baku, bahan penolong dan bahan produksi seperti yang disajikan pada Tabel 3 .

Tabel 3. Bahan baku, bahan penolong dan bahan produksi dalam satu kali produksi pada UD. Warna Sari Narmada

\begin{tabular}{lll}
\hline No & Bahan & Jumlah \\
\hline 1. & $\begin{array}{l}\text { Bahan baku } \\
\text { Nangka 1 buah }\end{array}$ & $8 \mathrm{~kg}$ \\
2. & $\begin{array}{l}\text { Bahan penolong : } \\
\text { Gula pasir }\end{array}$ & $4 \mathrm{~kg}$
\end{tabular}

3. Bahan penunjang
a. bahan kemasan kertas minyak 5 lembar kertas jagung 2 ikat kotak plastik $\quad 37$ kotak
b. bahan bakar minyak tanah atau gas 1 liter untuk minyak tanah atau 3 kg untuk gas

Sumber : (Astuti, 2019)

Proses pembuatan dodol nangka dengan cara sebagai berikut : buah nangka dikupas terlebih dahulu, dan dipisahkan dari kulit, dami, dan biji. Setelah itu dikukus selama 25 menit dan ditumbuk ditumbuk tidak terlalu 
halus agar nangka banyak mengandung serat. Nangka yang sudah ditumbuk lalu ditimbang dan dicampurkan dengan gula dengan perbandingan 2;1 seperti yang disajikan pada Tabel 1. Setelah itu dilakukan pemasakan selama kurang lebih 2,5 jam sampai warna adonan dodol berubah menjadi coklat dan mengental, lalu angkat. Angkat keloyang Tunggu sampai dingin kemudian dilakukan pemotongan menjadi bentuk segiempat, lalu dikemas menggunakan klobot/kulit jagung dan dijemur dibawah sinar matahari sampai kering. Dodol siap dikemas menggunakan kertas minyak dan siap dikonsumsi dan dijual.

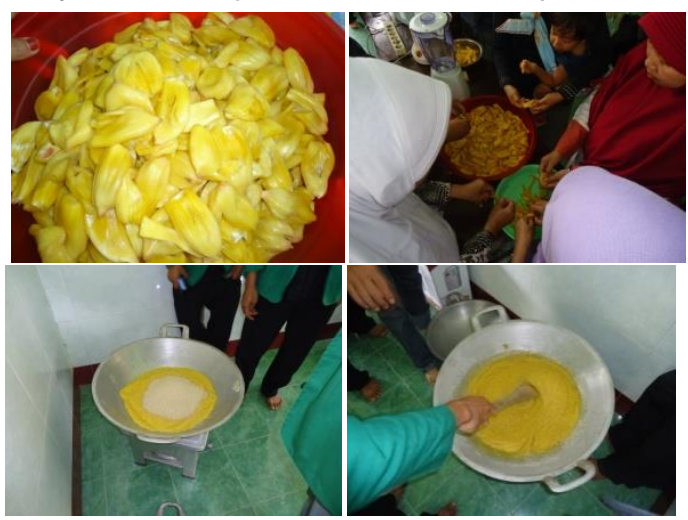

Gambar 4. Pelatihan pengolahan dodol nangka

Demonstrasi pembuatan dodol ini dilakukan hanya sampai tahap dodol basah, karena waktu yang tidak mencukupi dimana dodol harus dilakukan proses pengeringan sampai dodol kering yang ditandai dengan terbentuknya Kristal dibagian luar dodol. Proses pengeringan (lama dan suhu) sangat menentukan kualitas dari dodol yang dihasilkan. Factor lain yang menentukan dalam pembuatan dodol nangka adalah tingkat kemasakan buah. Buah nangka yang akan dijadikan dodol adalah buah yang bermutu baik dan matang karena akan menentukan titik akhir produk dodol nangka.

Proses pembuatan dodol nangka tidak sulit karena menggunakan alat yang sederhana. Sehingga dapat diusahakan dalam skala kecil atau industri rumah tangga. Selain bertujuan untuk mengawetkan, pembuatan dodol nangka juga dapat menambah keanekaragaman produk olahan dari buah nangka (Widyastuti, 1993).

Pengolahan susu biji nangka hampir sama dengan susu kedelai. Pengolahan susu biji nangka yang digunakan menggunakan metode (Dennis, 2017) yang telah dimodifikasi. Proses pembuatan susu biji nangka antara lain sebagai berikut: (1) Biji nangka direndam selama 12 jam, hingga kulitnya terkelupas. (2) Biji nangka direbus selama 15 menit atau sampai mendidih (3) Biji nangka diblender sampai halus dan ditambahkan air dengan perbandingan 1:3 (biji nangka : air) dan pure biji nangka yang dihasilkan disaring. (4) Filtrat biji nangka yang dihasilkan ditambahkan gula pasir untuk menghilangkan bau langu pada aroma biji nangka, lalu direbus sambil diaduk sampai suhu $90^{\circ} \mathrm{C}$, setelah itu ditambahkan daun pandan atau sari jahe sebagai bahan tambahan untuk menambah cita rasa dan aroma. Selainitu jahe digunakan sebagai penambah daya tahan tubuh.

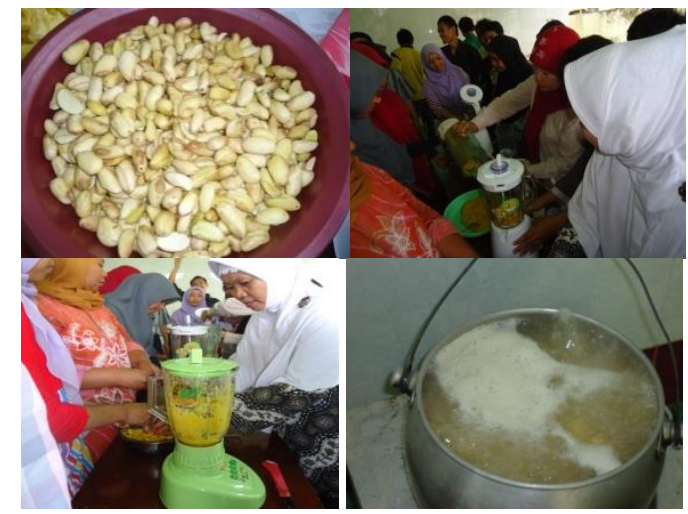

Gambar 5. Pelatihan pengolahan susu biji nangka

Secara umum kegiatan pengolahan dodol nangka dan susu biji nangka yang disampaikan kepada para peserta kegiatan, dirasakan sangat efektif karena semua peserta aktif dan terlibat dalam melaksanakan setiap tahap demi tahap semua proses pengolahan yang dilakukan.

Dari hasil pengamatan di lapang juga terlihat adanya permasalahan lain yang dihadapi peserta tidak hanya belum optimalnya pemanfaatan sumber daya yang dimiliki seperti nangka dan limbahnya berupa biji nangka tetapi sarana air bersih. Terbukti dengan konsumsi air minum harian mahasiswa KKN dengan air mineral serta pada saat akan melakukan demonstrasi, air yang digunakan untuk mencuci peralatan masih keruh.

\section{SIMPULAN DAN SARAN}

Berdasarkan hasil kegiatan pengabdian pada masyarakat, maka dapat disimpulkan : Pelaksanaan kegiatan pengabdian pada masyarakat ini berlangsung dengan sukses dan lancar sesuai dengan rencana. Kegiatan pengabdian pada masyarakat ini mampu meningkatkan pengetahuan masyarakat tentang nutrisi, manfaat dan olahan nangka. Selain itu juga meningkatkan keterampilan peserta penyuluhan untuk mengolah dodol nangka dan susu biji nangka. Berdasarkan hasil dari kegiatan pengabdian pada masyarakat dapat di sarankan hal-hal sebagai berikut 
peserta penyuluhan dapat memanfaatkan pengetahuan yang diperolehnya untuk usaha meningkatkan pendapatan keluarganya melalui usaha rintisan dodol nangka serta pemenuhan gizi keluarga melalui aplikasi teknologi pengolahan susu biji nangka. Perlu diadakan kegiatan penyuluhan strategi pemasaran dan pendampingan unit rintisan.

\section{DAFTAR RUJUKAN}

Andyarini, E. N., \& Hidayati, I. (2017). (ANALISIS PROKSIMAT PADA TEPUNG BIJI NANGKA (Artocarpus Heterophyllus Lamk.). KLOROFIL, 1(1), 32-37.

Astuti, E. (2019). Laporan Praktek Kerja Lapangan ASPEK PENGOLAHAN DAN PENGAWASAN MUTU KERIPIK NANGKA DI UD. WARNA SARI DESA SURANADI KEC. NARMADA. Fakultas Pertanian Universitas Muhammadiyah mataram.

BPOM. (2007). Acual label Gizi Produk Pangan No HK.00.05.52.6291. https:standarpangan.pom.go.id

Data Komposisi Pangan Indonesia. (2018). Data Komposisi Pangan Indonesia Beranda. https://www.panganku.org/idID/semua nutrisi

Dennis, E. (2017). ASPEK PENGOLAHAN DAN PENGAWASAN MUTU KERIPIK NANGKA DI UD. WARNA SARI DESA SURANADI KEC. NARMADA. Fakultas Keguruan dan IImu Pendidikan Universitas Sanata Dharma.

Hadi, N., Efendi, R., Studi, P., Hasil, T., Pertanian, J. T., Pertanian, F., \& Riau, U. (2017). Jagung Dalam Pembuatan Flakes Utilization of Jackfruit Seed Flour and Corn. 4(2), 1-12.

Haryadi. (2006). Teknologi Pengolahan Beras. Gadjah Mada University Press.

Hossain, M. T. (2014). Development and Quality Evaluation of Bread Supplemented with Jackfruit Seed Flour. International Journal of Nutrition and Food Sciences, 3(5), 484. https://doi.org/10.11648/j.ijnfs.2014030 5.28

Ihromi, S., Marianah, \& Nurhayati. (2020). IbM INOVASI TEKNOLOGI OLAHAN BERBASIS PISANG UNTUK PEMBERDAYAAN EKONOMI WANITA TANI DI SEKITAR HUTAN LINDUNG SESAOT DESA PAKUAN KECAMATAN NARMADA. Jurnal Agro Dedikasi Masyarakat, 1, 7.

Maurya, P, \& Mogra, R. (2016). Assessment of consumption practices of jackfruit (Artocarpus heterophyllus lam.) seeds in villages of Jalalpur block district Ambedarnagar (U.P.) India. Remarking, 2, 73-75.

Nusa, M., I., Fuadi, M., \& Fatimah, S. (2014). STUDI PENGOLAHAN BIJI BUAH NANGKA DALAM PEMBUATAN MINUMAN INSTAN. Agrium, 19(1), 3138.

Mukprasirt, A., \& Sajjaanantakul, K. (2004). Physico-chemical properties of flour and starch from jackfruit seed. Intl $J$ Food Sci Technol, 39(3), 271-276.

Nisak, S.M., Ida bagus Putu G., dan I Made Anom, \& S.W. (2014). Penentuan Umur Simpan Dodol Nangka dengan Metode ESS (extended Storage Studies). Jurnal BETA (Biosistem Dan Teknik Pertanian), 2(2).

Rachmawati, R. (2011). PEMBUATAN SARI BIJI NANGKA SEBAGAI MINUMANUNTUK MEMENUHI KEBUTUHAN FOSFOR. FAKULTAS TEKNIK UNIVERSITAS NEGERI YOGYAKARTA.

Setiavani, G., Ahza, A. B., \& Suyatma, N. E. (2018). Teknologi Pengolahan dan Peningkatan Nilai Gizi Dodol Processing Technology and Nutritional Improvements of Dodol. Pangan, 27(3), 14.

Sutarto, S., Mayasari, D., \& Indriyani, R. (2018). Stunting, Faktor Resiko dan Pencegahannya. J Agromedicine, 5(1), 540-545.

Swami, S. B., Thakor, N. J., Haldankar, P. M., \& Kalse, S. B. (2012). Jackfruit and Its Many Functional Components as Related to Human Health: A Review. Comprehensive Reviews in Food Science and Food Safety, 11(6), 565576. https://doi.org/10.1111/j.15414337.2012.00210.x

Umesh, J., Panaskar, S. N., \& Bapat, V. (2010). Evaluation of antioxidant capacity and phenol content in jackfruit (Artocarpus heterophyllus Lam.)fruit pulp. Plant Foods Hum Nutr, 65, 99-104.

Waghmare, R., Memon, N., Gat, Y., Gandhi, S., Kumar, V., \& Panghal, A. (2019). Jackfruit seed: An accompaniment to functional foods. Brazilian Journal of Food Technology, 22, 1-9. https://doi.org/10.1590/19816723.20718

Wulandari, R., Ishartani, D., \& Anandito, R. B. K. (2014). STUDY OF THE USE OF JACK FRUIT (Artocarpus heterophyllus) SEED FLOUR IN THE SENSORY. 3(4), 7. 